\title{
Comprehensiveness and programmatic vulnerability to STDS/HIV/AIDS in primary care*
}

\author{
A INTEGRALIDADE E A VULNERABILIDADE PROGRAMÁTICA ÀS DST/HIVIAIDS NA \\ ATENÇÃO BÁSICA
}

\section{LA INTEGRALIDAD Y VULNERABILIDAD PROGRAMÁTICA DE LAS ETS/VIH/SIDA EN LAATENCIÓN BÁSICA}

\author{
Luciane Ferreira do Val ${ }^{1}$, Lucia Yasuko Izumi Nichiata ${ }^{2}$
}

\begin{abstract}
This study aimed to identify programmatic vulnerability to STDs/HIV/AIDS in primary health centers (PHCs). This is a descriptive and quantitative study carried out in the city of São Paulo. An online survey was applied (FormSUS platform), involving administrators from 442 PHCs in the city, with responses received from 328 of them (74.2\%), of which $53.6 \%$ were nurses. Attention was raised in relation to programmatic vulnerability in the PHCs regarding certain items of infrastructure, prevention, treatment, prenatal care and integration among services on STDs/HIV/AIDS care. It was concluded that in order to reach comprehensiveness of actions for HIV/ AIDS in primary health care, it is necessary to consider programmatic vulnerability, in addition to more investment and reorganization of services in a dialogue with the stakeholders (users, multidisciplinary teams, and managers, among others).
\end{abstract}

\section{RESUMO}

Objetivo: Identificar a vulnerabilidade programática às DST/HIV/aids na Atenção Básica para o enfrentamento do HIV/Aids. Método: Estudo descritivo, com abordagem quantitativa, realizado no Município de São Paulo (MSP). Utilizou-se formulário online (FormSUS), com gerentes das 442 Unidades Básicas de Saúde (UBS) do MSP. Participaram do estudo $74,2 \%$ gerentes, dos quais $53,6 \%$ eram enfermeiros. Resultados: Destaca-se a vulnerabilidade programática nas UBS com relação a alguns itens de infraestrutura, ações de prevenção, de tratamento, no pré-natal e de integração entre os serviços na atenção às DST/HIV/aids. Conclusão: Para a efetivação da integralidade no enfrentamento do HIV/ aids na Atenção Básica é necessário atentar para a vulnerabilidade programática, além de mais investimentos e reorganização dos serviços, num diálogo com os atores sociais envolvidos (usuários, equipe multiprofissional, gerentes, gestores, entre outros).

\section{DESCRITORES}

Doenças sexualmente transmissíveis Síndrome da imunodeficiência adquirida Vulnerabilidade em saúde Integralidade em saúde Atenção Primária à Saúde Enfermagem em saúde pública

\section{RESUMEN}

Objetivo: Fue identificar la vulnerabilidad programática de las Unidades Básicas de Salud con la atención a las ETS/VIH/SIDA. Método: Es un estudio descriptivo con un abordaje cuantitativo llevado a cabo en el Municipio de San Pablo. Fue utilizado un formulario online (el FormSUS) con los gerentes de las 442 Unidades Básicas de Salud del Municipio de San Pablo. Participaran en el estudio $74.2 \%$ de los gerentes, estos $53.6 \%$ eran enfermeros. Resultados: Se destaca la vulnerabilidad programática de las Unidades Básicas de Salud en relación a algunos elementos de la infraestructura, acciones de prevención, tratamiento, prenatal y la integración entre los servicios en la atención a las ETS/VIH/SIDA. Conclusión: Para efectividad de la integralidad en el enfrentamiento de la HIV/SIDA en la atención básica es necesario considerar la vulnerabilidad programática, y mucho más inversiones y reorganización de los servicios en un diálogo con los agentes sociales implicados (usuarios, equipo multidisciplinario, gerentes, y otros).

\section{DESCRIPTORES}

Enfermedades de transmisión sexual Síndrome de inmunodeficiencia adquirida Vulnerabilidad en salud Integralidad en salud Atención Primaria de Salud Enfermería en salud pública

*Extracted from the work "Vulnerabilidade ao HIV/aids: contribuição da pesquisa-ação no aprimoramento das ações de prevenção na Atenção Básica", 1st Exhibition of works of the Nursing graduate program, School of Nursing, University of São Paulo, 2013. ${ }^{1}$ Student of the post-doctorate program, School of Nursing, University of São Paulo, São Paulo, SP, Brazil. ${ }^{2}$ Associate Professor, Department of Collective Health Nursing, School of Nursing, University of São Paulo, São Paulo, SP, Brazil. 


\section{INTRODUCTION}

The year 2014 marks the 33rd year since American scientists reported the first occurrence of a disease that later came to be known as acquired immunodeficiency syndrome (AIDS).

In the period from 1980 through June 2012 in the city of São Paulo, there were reports of 81,300 cases of AIDS, 58,554 in males and 22,746 in females ${ }^{(1)}$. AIDS occurrences have been decreasing since 1997 as result of the introduction of the highly active antiretroviral therapy (HAART) treatment in 1996, decreasing the viral load in AIDS carriers and helping the decrease in virus transmission ${ }^{(2)}$. Despite this relative control, one of the challenges when confronting HIV/AIDS is to carry out expansion of prevention and early diagnosis actions in health services. Primary health centers (PHCs) carry out decentralized preventive actions to confront the HIV/AIDS epidemic in Brazil. In the past, such actions were limited to reference services. Primary care has been developing actions focused on confronting HIV/AIDS on different levels and qualities and it also points to great challenges in the development of said actions. Among those actions is the increase in early diagnosis, since more than half of the people with a confirmed disease already present immunological deterioration at the time of diagnosis. In addition to that problem, others related to prolonged treatment are of notice, such as non-adherence to treatment with ARV drugs, which may lead to the virus resisting the drugs and even to failure of treatment in many cases. Other strategies to confront the epidemic are the improvement of actions against tuberculosis/HIV coinfection and integration of health services ${ }^{(3)}$.

PHCs improve comprehensiveness of care ${ }^{(4)}$. They are considered special places for care, both when performing their traditional role or as Family Health Strategies (Estratégias Saúde da família). However, implementing comprehensiveness on primary care is one of the great challenges in confronting STDs/HIV/AIDS.

Comprehensiveness has a set of characteristics, which include the health system, its institutions and the organization of desirable practices, as well as the challenge of building justice, democracy and effective health access through various technological densities, knowledge and practices, according to the necessities of each individual, in a supportive manner ${ }^{(5)}$.

Comprehensiveness, when it comes to organizing practices, aims to end divisions between public health and medical assistance, and between preventive and healing (curative) actions. It is also where users' necessities are not reduced to the technical knowledge of health professionals(5).

The principle of comprehensiveness in the organization of primary health services demands horizontal health practices from programs that were previously vertical.
However, teams at health centers no longer base care on the medical approach and on specific programs from the Brazilian Ministry of Health, but rather on the epidemiological approach, in other words, offering services to exclusively treat the diseases of a population ${ }^{(5)}$.

Considering the history of the city of São Paulo in confronting HIV/AIDS and lack of knowledge regarding the organization of the PHCs concerning HIV/AIDS care, this study had as its objective the identification of signs of programmatic vulnerability (PV) to STDs/HIV/AIDS on primary health in the city of São Paulo to confront HIV/AIDS.

\section{METHOD}

It is a descriptive, exploratory study whose reference is the concept of vulnerability, regarding its programmatic aspect $^{(6-7)}$, in other words, the conditions of structure, dynamics, organization and operationalization of actions for confronting HIV/AIDS, in this case in primary health services.

The concept of vulnerability includes a set of collective contexts that are interconnected and that enable a higher exposure to or lower protection against HIV/AIDS. It is different from the concept of risk, which is central to epidemiological studies. The operationalization of vulnerability makes it possible to objectively, ethically and politically evaluate the life conditions of individuals and groups that are exposed to the problem and the elements that support the construction of real alternatives to confront this problem. It is understood that a person's disease is determined by a set of conditions that are not limited just to the person's behavior and to the biological aspects of the infection. The person is in an economic, cultural and socio-political context of availability of healthcare services that may reinforce protection against the disease ${ }^{(8-9)}$.

The study's subjects were the administrators of the PHCs linked to the São Paulo Municipal Secretary of Health (Secretaria Municipal de Saúde de São Paulo). The instrument used in data gathering was based on two forms: the first one called Monitoring of the decentralization processes of actions on STDS/AIDS in primary care, developed by the Reference Center for Treatment of STDs/AIDS, SP, of the São Paulo State Secretary of Health ${ }^{(10)}$, and the second one called Evaluation for the improvement of quality of the Family Health Strategy $(E I Q)^{(11)}$.

An online form was created on the FormSUS platform. It had 51 questions and was sent to the administrators of 442 PHCs in the period from April to September 2011. The analysis of comprehensiveness in HIV/AIDS care in the PHCs was guided by five signs of programmatic vulnerability: a) Infrastructure for the performance of preventive and care actions in STDs/HIV/AIDS, composed of 16 items; b) Responses for the necessities of STDs/HIV/AIDS care, composed of seven items; c) Prenatal and puerperium actions 
regarding STDs/HIV/AIDS care, composed of 11 items; d) Preventive actions regarding STDs/HIV/AIDS, composed of 10 items; and e) Integration of actions among PHCS, STD/ Aids Reference Center CRT/SAE for HIV/STDs/AIDS and maternity hospitals, composed of 8 items ${ }^{(12)}$.

The responses were classified as meets and does not meet the item criteria according to recommendations from the Brazilian Ministry of Health, the São Paulo State Secretary of Health and the Municipal Secretary of Health, awarding them respective values of 1 and 0 . A cut-off percentage of $80 \%$ was considered for each analyzed item.

To analyze the data, we used the Statistical Package for the Social Sciences (SPSS), version 19, in which data were presented descriptively in charts and graphs including absolute (number) and relative (\%) frequency.
The project was approved by the Research Ethics Committee of the School of Nursing (EEUSP), process number 783/2006, and by the Research Ethics Committee of the São Paulo Municipal Secretary of Health, under the number 366/2009, CAAE 0174.0162.000-09.

\section{RESULTS}

Participants in the study were 328 (74.2\%) administrators of PHCs of the city of São Paulo; of these, 176 (53.6\%) were nurses.

Despite the fact that the PHCs in the study met most of the evaluated item criteria, it was possible to identify programmatic vulnerability in primary care for STDs/HIV/ AIDS (table 1).

Table 1 - Distribution of programmatic vulnerability signs and affirmative responses to the items - city of São Paulo, SP, 2012.

\begin{tabular}{|c|c|c|}
\hline Programmatic vulnerability signs & Affirmative & items $(\mathrm{N}=\mathbf{3 2 8})$ \\
\hline Infrastructure for the performance of preventive and STDs/HIV/AIDS care actions (16 items) & $\mathbf{N}^{0}$ & $\%$ \\
\hline A. Exam rooms have visual/auditory privacy for STDs/HIV/AIDS appointments. & 275 & 83.8 \\
\hline B. Room for the performance of educational activity. & 267 & 81.4 \\
\hline C. Availability of basic materials for educational activity. & 242 & 73.8 \\
\hline D. Steady supply of materials for contraception and prevention: Pill. & 325 & 99.1 \\
\hline E. Steady supply of materials for contraception and prevention: Injectable. & 297 & 90.5 \\
\hline F. Steady supply of materials for contraception and prevention: IUD. & 254 & 77.4 \\
\hline G. Steady supply of materials for contraception and prevention: Male condom. & 306 & 93.3 \\
\hline H. Quantity of materials for contraception and prevention: Pill. & 322 & 98.2 \\
\hline I. Quantity of materials for contraception and prevention: Injectable. & 294 & 89.6 \\
\hline J. Quantity of materials for contraception and prevention: IUD. & 270 & 82.3 \\
\hline K. Quantity of materials for contraception and prevention: Male condom. & 284 & 86.6 \\
\hline L. Quantity of laboratory exams: Syphilis. & 327 & 99.7 \\
\hline M. Quantity of laboratory exams: Anti-HIV. & 328 & 100.0 \\
\hline N. Quantity of laboratory exams: Hepatitis B serology. & 328 & 100.0 \\
\hline O. Daily collection of laboratory exams in general. & 326 & 99.4 \\
\hline P. Exams for immediate pregnancy in case of late period. & 324 & 98.8 \\
\hline Responses to necessities of STDs/HIV/AIDS care (7 items) & $\mathbf{N}^{\mathbf{0}}$ & $\%$ \\
\hline A. Going through treatment with benzatin penicillin when a pregnant woman is diagnosed with syphilis. & 289 & 88.1 \\
\hline $\begin{array}{l}\text { B. Indicate treatment with benzatin penicillin without requisition or exam results from the partner of a } \\
\text { pregnant woman with syphilis diagnosis. }\end{array}$ & 213 & 64.9 \\
\hline C. Going through candidiasis treatment. & 328 & 100.0 \\
\hline D. Going through syphilis treatment. & 327 & 99.7 \\
\hline E. Going through trichomoniasis treatment. & 322 & 98.2 \\
\hline F. Going through chlamydia treatment. & 298 & 90.9 \\
\hline G. Treatment is based on the syndromic approach. & 274 & 83.5 \\
\hline Prenatal and puerperium actions regarding STDs/HIV/AIDS care (11 items) & $\mathbf{N}^{\mathbf{0}}$ & $\%$ \\
\hline A. Schedules the first prenatal appointment within two weeks. & 308 & 93.9 \\
\hline B. Offering a pap exam for pregnant women is standard procedure. & 306 & 93.3 \\
\hline C. Offers syphilis test for pregnant women during the $1^{\text {st }}$ and $3^{\text {rd }}$ trimesters of pregnancy. & 203 & 61.9 \\
\hline D. Tested for Hepatitis B in prenatal period. & 325 & 99.1 \\
\hline E. Tested for Hepatitis $\mathrm{C}$ during pregnancy. & 299 & 91.2 \\
\hline F. Tested for HIV in prenatal period. & 220 & 67.1 \\
\hline G. Performs consented approach to request HIV test from pregnant women. & 256 & 78.0 \\
\hline H. Notification of HIV diagnosis to pregnant women is performed by a multiprofessional team. & 119 & 36.3 \\
\hline I. Performs active search for the attendance of partners of pregnant women with HIV diagnosis. & 322 & 98.2 \\
\hline J. Notifies pregnant women of the syphilis diagnosis. & 327 & 99.7 \\
\hline K. There is a reference hospital to perform childbirth for HIV-positive pregnant women. & 316 & 96.3 \\
\hline
\end{tabular}

$\mathrm{K}$. There is a reference hospital to perform childbirth for HIV-positive pregnant women. 


\begin{tabular}{|c|c|c|}
\hline Programmatic vulnerability signs & Affirmative $r$ & tems $(\mathrm{N}=328)$ \\
\hline Preventive actions regarding STDs/HIV/AIDS (10 items) & $\mathbf{N}^{\mathbf{0}}$ & $\%$ \\
\hline A. Professionals trained to perform syndromic approach care for STDs. & 168 & 51.2 \\
\hline B. Professionals trained to perform counseling when offering HIV test. & 119 & 36.3 \\
\hline C. Performs action for the attendance of the partner in case of STD. & 319 & 97.3 \\
\hline D. Performs action for the attendance of the partner in specific case of HIV. & 319 & 97.3 \\
\hline E. Performs active search for users who carry STDs when they do not come to the center. & 318 & 97.0 \\
\hline F. Multiprofessional team records notifications of positive exams for the detection of syphilis. & 182 & 55.5 \\
\hline G. Performs HIV test for the general population any day of the week. & 304 & 92.6 \\
\hline H. Performs counseling for the HIV exam. & 35 & 10.7 \\
\hline I. The average response time for the results of positive HIV exams to the center is up to seven days. & 126 & 38.4 \\
\hline J. Performs consented approach when requesting HIV exam. & 251 & 76.5 \\
\hline Integration of actions between UBS, CRT/SAE on HIV/STDs/AIDS and maternity hospitals (8 items) & $\mathbf{N}^{\mathbf{0}}$ & $\%$ \\
\hline A. There is a continuous stream of notifications for congenital syphilis in the maternity hospital. & 295 & 89.9 \\
\hline B. Notifies pregnant women of the HIV diagnosis. & 313 & 95.4 \\
\hline $\begin{array}{l}\text { C. Provides referral forms and registers appointments on the STDs/AIDS CRT and SAE reference } \\
\text { services for pregnant women diagnosed with HIV. }\end{array}$ & 206 & 62.8 \\
\hline $\begin{array}{l}\text { D. Information is sent back to the center after referring pregnant women to reference services for } \\
\text { STDs/AIDS CRT and SAE. }\end{array}$ & 224 & 68.3 \\
\hline E. Information is sent back to the center regarding childbirth of referred pregnant women with HIV. & 239 & 72.9 \\
\hline $\begin{array}{l}\text { F. Makes an appointment with the reference service for STDs/AIDS when there is a positive } \\
\text { result for HIV. }\end{array}$ & 205 & 62.5 \\
\hline $\begin{array}{l}\text { G. There is a stream of references/counter-references for patients referred to special treatment ser- } \\
\text { vices for STDs/AIDS. }\end{array}$ & 93 & 28.4 \\
\hline H. Follows up the cases referred to reference service for STDs/AIDS. & 279 & 85.1 \\
\hline
\end{tabular}

In table 1, in the section Infrastructure for the performance of preventive and STDS/HIV/AIDS care actions, it was noted that there are $86(26.2 \%)$ PHCs that do not have basic materials for educational activities and 74 (22.6\%) that do not have a steady supply of materials for contraception and prevention, such as the intrauterine device (IUD).

With regard to Responses to necessities of STDs/HIV/ AIDS care, 115 (35.1\%) of the PHCs do not indicate treatment with benzatin penicillin for the partners of pregnant women diagnosed with syphilis without exam requisitions or results, contrary to what is recommended.

In Prenatal and puerperium actions regarding care for STDS/HIV/AIDS, it was noted that 125 (38.1\%) of the PHCs do not offer syphilis tests for pregnant women in the first and third trimesters of pregnancy; 108 (32.9\%) do not perform HIV tests in the prenatal period; 72 (22\%) do not perform consented approach to request HIV tests from the pregnant women; and in 209 (63.7\%) the notification to pregnant women of HIV diagnosis is not performed by a multiprofessional team.

In the part for Preventive actions regarding STDs/HIV/ AIDS, professionals are not adequately trained for syndromic approach care in 160 (48.8\%) of the PHCs. In 209 $(63.7 \%)$, professionals are not adequately trained to perform counseling when offering HIV tests. In 146 (44.5\%), it is not the multiprofessional team that records notifications of positive exams for the detection of syphilis. Counseling for HIV tests is not performed in 293 (89.3\%) of the PHCs; in 202 (61.6\%), the average response time for the results of positive HIV tests was more than seven days; and in $77 \%(23.5 \%)$, there are no consented approaches when requisitioning the HIV tests.

Among the signs, there is one that concerns integration of actions between UBS, CRT/SAE on HIV/STDs/AIDS and maternity hospitals, which refers to the communication from primary care toward other centers (both reference services of care for HIV/AIDS and monitoring services). This was the one with the lowest percentage of PHCs that claimed to perform actions in that respect. There is no return of information to the center after the referral of pregnant women to STDs/AIDS reference services in 104 (31.7\%), and regarding childbirth, 89 (27.1\%) show no stream of reference/counter-reference of patients referred to STDs/AIDS specialized centers in 235 (71.9\%) PHCs.

\section{DISCUSSION}

A fact that draws attention when analyzing programmatic vulnerability in PHCs in the city of São Paulo is that nurses are administrators in many of them. Historically, nurses have performed management and coordination duties in health centers, work fields and nursing teams in Brazil ${ }^{(13)}$. Management is an important tool for nurses to promote in multidisciplinary teams a thinking process and review of their practice in order to (re)organize service with commitment to health care, not just performing fragmented actions or isolated procedures ${ }^{(14)}$.

Because of implementation of the Brazilian Unified Health System and consequent decentralization of health services (decisions are closer to the local sphere and to 
service users), it is necessary that PHC managers have new knowledge and skills. Comprehensiveness as the guide of administrative activity and instigator of changes in the dominant medical care model must be built on the basis of dialog between training and work, construction of knowledge, relation of theory and practice and a search for reflection on health actions ${ }^{(14)}$.

Concerning the organization of practices for STDs/HIV/ AIDS care in PHCs, administrators and multidisciplinary teams may be bringers of change to realize comprehensiveness. Health comprehensiveness is thought of as a light beam ${ }^{(15),}$ subject to the same physical phenomena, such as properties of reflection, refraction or absorption, suggesting that the bringers return to their starting place if they are reflected when trying to pass through an obstacle. Therefore, the second time, they break barriers and cross spaces, even if they suffer a coefficient of refraction and deflection. The bringers of comprehensiveness would thus break barriers when constructing new ways of doing/ acting in daily practice.

Nurses as administrators and multidisciplinary teams as bringers of change respond to the necessities of treatment, perform prenatal and puerperium actions in relation to STD care and take part in actions with reference services for STDs/HIV/AIDS when they implement preventive and care actions for STDs/HIV/AIDS. Even if they sometimes face hardships passing through obstacles, translated as PVs, these bringers of change, enlightened by comprehensiveness, have the power to build new ways of doing/acting in the daily services practice. Thus, new institutional arrangements, focused on users, may be produced when their vulnerabilities and potentials are considered and citizens' rights are respected, as guided by the principle of comprehensiveness.

Analysis of signs of programmatic vulnerability (PV) in HIV/AIDS care in PHCs of São Paulo's Secretary of Municipal Health showed challenges that must be overcome. It is important to note that the concept of PV includes a sense that there is power to overcome the conditions that lead to vulnerability; therefore, the relation vulnerability/ emancipation is dialectically defined. There is vulnerability in the same measure that there are conditions to confront the situation.

In relation to Infrastructure for the performance of preventive and STDS/HIV/AIDS care actions, the study showed that there are not enough educational materials and other prevention materials such as IUDs in the researched PHCs. This problem was identified in other studies ${ }^{(16-17)}$.

In Responses to necessities of STDS/HIV/AIDS care, it is noted that most of the PHCs do not perform the benzatin penicillin treatment on the partners of pregnant women with a syphilis diagnosis, even without the results of the laboratory exam, as defined by ordinance number 3,161 , December 27, 2011 $11^{(18-19)}$.
It is known that one obstacle to eliminating congenital syphilis is difficulty in treating the partner of the diagnosed pregnant woman. In the state of São Paulo it is estimated that only $14 \%$ of partners of pregnant women with syphilis are adequately treated, which indicates problems related to prenatal care quality ${ }^{(20)}$.

As for Prenatal and puerperium actions regarding STDS/HIV/AIDS care, it was verified that there are challenges to be overcome, especially related to the offer of anti-HIV testing and syphilis testing in the first and third trimester of pregnancy.

In fact, that is a problem in many places. In the study Resultado do estudo sentinela-parturiente, ${ }^{(21)}$ it was verified that only $14.1 \%$ of parturient women who received care in the 150 maternity hospitals of the Brazilian Unified Health System were tested twice for syphilis during pregnancy, as recommended, and that there is low coverage for the second prenatal syphilis test, which shows that the recommendations of the Brazilian Ministry of Health are not being followed.

In a study regarding coverage for anti-HIV testing during pregnancy, interviews with 435 women from five municipalities of the northwestern part of the state of Paraná, Brazil, revealed coverage of $89.6 \%$, which is far from ideal-coverage should be $100 \%$. In another study, the result was only coverage of $48.4 \%$ for pregnant women in five Family PHCs in the city of Cuité, state of Paraíba, Brazil(23).

Another challenge is the counseling of the pregnant woman before and after the anti-HIV test by members of the multiprofessional team. Counseling must be carried out with the objective of humanization, at the moment of communicating information regarding results, be they negative or positive. In a study conducted with nurses in prenatal appointments in three Family Health Strategies centers in Fortaleza, state of Ceará, it was discussed that in care there is a prevalence of an I-THIS relationship between professionals and users, in other words, a subjectobject relation, instead of I-YOU, subject-subject relationship. This happens because of work demands that are measured quantitatively in terms of productivity, result in fast and mechanical appointments, without the possibility of offering humanized care ${ }^{(24)}$.

In the city of São Paulo, any professional trained for counseling can request HIV and syphilis exams (ordinance number 2,703, December 20, 2003) $)^{(25)}$. However, some of the city's PHCs have not incorporated this request in their practices, so the tests are performed without the adequate approach.

Testing has been increasing in Brazil, but without offering of counseling, without due attention to people's independent decisions, and with inequalities regarding educational level, region and ethnicity ${ }^{(26)}$

On the item Preventive actions regarding STDs/HIV/AIDS, it was noticed that there was a big problem with receiving 
results of HIV tests within seven days. According to administrators of the PHCs of 30 municipalities of the state of São Paulo, one study found that in $28.1 \%(n=305)$ of the PHCs there was a delay of up to 15 days in receiving syphilis, HIV and Hepatitis B exam results; in $7.1 \%(n=263)$ around 16 to 30 days; and in $3.2 \%(n=340)$ more than 31 days $^{(18)}$.

The labs have complex issues that make it difficult to establish a stream of care for users of PHCs, such as: lack of regulation and supervision of third-party labs; fragmentation of exam types among many lab; performance of exams that are conditioned to the operational capacity of the kits; and restrictive quotas for the performance of exams, among others ${ }^{(18)}$.

On Integration of actions between PHCS, CRT/SAE on HIV/STDs/AIDS and maternity hospitals, there is one of the critical issues to be confronted, which deals with the reference and counter-reference stream from PHCs to other centers in the care network. It is a sign of fragmentation in health care. Other studies have shown that the reference and counter-reference system have been a problem for multiprofessional teams, since the mid-1980s, independent of the level of care (primary, secondary or tertiary), the event or the relevant disease. ${ }^{(27-28)}$.

Comprehensiveness in care has not been materialized because decentralization and regionalism prevented the integration process in services at different care levels and the formation of healthcare networks. There is an imbalance in the number of PHCs for the number of inhabitants; the service network at the second and third levels is not sufficient; the same applies to human resources, as professionals are not trained for activities that demand specific qualifications; and there are operational problems in information systems. All of these factors, among others, result in

\section{REFERENCES}

1. Boletim Epidemiológico de AIDS, HIV e DST do Município de São Paulo. Secretaria Municipal da Saúde, Coordenação de Vigilância em Saúde, São Paulo. 2012;15(16).

2. Boletim Epidemiológico de AIDS, HIV/DST e Hepatites B e C do Município de São Paulo. Secretaria Municipal da Saúde, Coordenação de Vigilância em Saúde, São Paulo. 2011;15(14).

3. Paula IA, Guibu IA. DST/aids e rede básica: uma integração necessária. São Paulo: Secretária de Estado da Saúde; 2007.

4. Brêtas ACP, Pereira AL. Gestão em unidades básicas de saúde. In: Harada MJCS, organizador. Gestão em enfermagem: ferramenta para prática segura. São Caetano do Sul (SP): Yendis; 2011. p. 377-83. resource fragmentation and detachment from attention to the health necessities of the population ${ }^{(29)}$.

Comprehensiveness requires that PHCs be closely linked to other health services, in order to offer all types of healthcare services (including referrals to other services), making their responsibility clear both for users and teams. The latter, in addition to knowing how to identify user problems (functional, organic and social), must offer and recognize necessities for care and preventive services ${ }^{(30)}$.

\section{CONCLUSION}

The study reached its objective of identifying signs of programmatic vulnerability (PV) to STDs/HIV/AIDS in primary care in the city of São Paulo. In addition, it identified that most PHC administrators are nurses and, therefore, how important it is for these professionals to unite scientific knowledge, political competence and the ethical sense of care in order to adequately manage PHCs to confront HIV/AIDS.

For the materialization of comprehensiveness in STDs/ HIV/AIDS care in primary care, investments and service reorganization are essential, taking the PVs into account in a dialog with the stakeholders (users, multiprofessional teams, administrators, and managers among others).

Technological advances, especially related to treatment of STDs/HIV/AIDS, are no substitutes for the search for improvement in actions at the programmatic level of primary care; on the contrary, they reinforce the need for their own incorporation in PHCs because of their geographically central position in coordination with other centers in the service network.
5. Mattos RA. Os sentidos da integralidade: algumas reflexões acerca de valores que merecem ser defendidos. In: Pinheiro $\mathrm{R}$, Mattos RA, organizadores. Os sentidos da integralidade na atenção e no cuidado à saúde. 8ª ed. Rio de Janeiro: CEPESC/ IMS/UERJ/ABRASCO; 2009. p. 43-68.

6. Mann J, Tarantola DJM, Netter T. Como avaliar a vulnerabilidade à infecção pelo HIV e aids. Rio de Janeiro: Relume-Dumará; 1993. A Aids no mundo; p. 275-300.

7. Nichiata LYI, Bertolozzi MR, Gryschek ALFPL, Araújo NVDL, Barbosa MCPF, Ciosak SI, et al. The potential of the concept of vulnerability in understanding transmissible diseases. Rev Esc Enferm USP [Internet]. 2011 [cited 2012 Feb 07];45(n. spe 2):1769-73. Available from: http://www.scielo.br/pdf/ reeusp/v45nspe2/en_23.pdf

8. Nichiata LYI, Bertolozzi MR, Takahashi RF, Fracolli LA. The use of the "vulnerability" concept in the nursing area. Rev Latino Am Enferm. 2008;16(5):129-35.
Comprehensiveness and programmatic vulnerability to stds/hiv/aids in primary care Val LF, Nichiata LYI 
9. Ayres JRCM, Paiva V, França Junior I. From natural history of disease to vulnerability: changing concepts and practices in contemporary public health. In: Parker $P$, Sommer $M$, organizadores. Routledge handbook in global public health. Abingon: Oxon: Taylor \& Francis; 2011. p. 98-107.

10. São Paulo (Estado). Secretaria de Estado da Saúde; Centro de Referência e Treinamento em DST/AIDS. Programa Estadual DST/Aids. Monitoramento da Atenção Básica [Internet]. São Paulo; 2011 [citado 2012 fev. 07]. Disponível em: http://formsus.datasus.gov.br/site/formulario.php?id_ aplicacao $=2557$

11. Brasil. Ministério da Saúde; Secretaria de Atenção à Saúde, Departamento de Atenção Básica. Autoavaliação para a Melhoria do Acesso e Qualidade da Atenção Básica: AMAQAB [Internet]. Brasília; 2012 [citado 2012 jul. 22]. Disponível em: http://dab.saude.gov.br/sistemas/amaq/

12. Val LF, Nichiata LYI. A integralidade na atenção às DST/HIV/ AIDS: a vulnerabilidade programática em unidades de saúde. Saarbrücken, Alemanha: Novas Edições Acadêmicas; 2014.

13. Alves M, Penna CMM, Brito MJM. Perfil dos gerentes de unidades básicas de saúde. Rev Bras Enferm. 2004;57(4):441-6.

14. Kawata LS, Mishima SM, Chirelli MQ, Pereira MJB. O trabalho cotidiano da enfermeira na saúde da família: utilização de ferramentas da gestão. Texto Contexto Enferm. 2009;18(2):313-20.

15. Santos AM, Assis MMA. Da fragmentação à integralidade: construindo e (des) construindo a prática de saúde bucal no Programa de Saúde da Família (PSF) de Alagoinhas, BA. Ciênc Saúde Coletiva. 2006;11(1):53-61.

16. Souza FO. Avaliação normativa das ações de testagem e aconselhamento para HIV em Unidades Básicas do Município de Manaus/AM [dissertação]. Manaus: Escola Nacional de Saúde Pública, Fundação Oswaldo Cruz; 2006.

17. Ferraz DAS. Avaliação da implantação das ações de prevenção das DST/aids numa Unidade de Saúde da Família [dissertação]. São Paulo: Faculdade de Medicina, Universidade de São Paulo; 2008.

18. Bersusa AAS, Gonçalves DA, Guibu IA, Paula IA. Entendendo a realidade dos serviços: análise dos resultados. In: Paula IA, Guibu IA, organizadores. DST/aids e rede básica: uma integração necessária. São Paulo: Secretaria de Estado da Saúde; 2007. p. 34-50.

19. Brasil. Ministério da Saúde. Portaria no 3.161, de 27 de dezembro de 2011. Dispõe sobre a administração da penicilina nas unidades de Atenção Básica à Saúde, no âmbito do Sistema Único de Saúde (SUS). Diário Oficial da União, Brasília, 28 dez. 2011. Seção 1, p. 54.
20. São Paulo (Estado). Secretaria de Estado da Saúde; Centro de Referência e Treinamento DST/AIDS. Programa Estadual DST/Aids. Implantação do pré-natal do homem [Internet]. São Paulo; 2012 [citado 2014 mar. 13]. Disponível em: http://www.saude.sp.gov.br/centro-de-referenciae-treinamento-dstaids-sp/acoes-programaticas/ implantacao-do-pre-natal-do-homem

21. Szwarcwald CL, Barbosa Junior A, Miranda AE, Paz LC. Resultados do Estudo Sentinela-parturiente, 2006: desafios para o controle da sífilis congênita no Brasil. DST J Bras Doenças Sex Transm. 2007;19(3-4):128-33.

22. Misuta NM, Soares DA, Souza RKT, Matsuo T, Andrade SM. Sorologia anti-HIV e aconselhamento pré-teste em gestantes na região noroeste do Paraná, Brasil. Rev Bras Saúde Mater Infant. 2008;8(2):197-205.

23. Matos SD, Baptista RS, França ISX, Medeiros FAL, Brito VRS. Conhecimento das gestantes atendidas nos serviços de prénatal acerca do teste anti - HIV. Rev RENE. 2009;10(2):122-30.

24. Araújo MAL, Farias FLR, Rodrigues AVB. Aconselhamento pósteste anti-HIV: análise a luz de uma teoria humanística de Enfermagem. Esc Anna Nery Rev Enferm. 2006;10(3):425-31.

25. São Paulo (Cidade). Secretaria Municipal da Saúde. Programa Municipal de DST/AIDS de São Paulo. Eliminação da transmissão vertical do HIV/aids e da sífilis. São Paulo; 2010.

26. Paiva V, Pupo LR, Barbosa R. O direito à prevenção e os desafios da redução da vulnerabilidade ao HIV no Brasil. Rev Saúde Pública. 2006;40 Supl:109-19.

27. Juliani CMCM, Ciampone MHT. Organização do sistema de referência e contra-referência no contexto do Sistema Único de Saúde: a percepção de enfermeiros. Rev Esc Enferm USP. 1999;33(4):323-33.

28. Maeda ST. Gestão da referência e contra referência na atenção ao ciclo gravídico puerperal: a realidade do Distrito de Saúde do Butantã [tese doutorado]. São Paulo: Escola de Enfermagem, Universidade de São Paulo; 2002.

29. Saito RXS. Integralidade a perspectiva da integração dos serviços para formação de redes de atenção: estudo de caso em uma região de saúde do município de São Paulo, Brasil [tese doutorado]. São Paulo: Escola de Enfermagem, Universidade de São Paulo; 2010.

30. Starfield B. Atenção primária: equilíbrio entre necessidades de saúde, serviços e tecnologia. Brasília: UNESCO/Ministério da Saúde; 2002.

\section{Acknowledgements}

The authors thank the São Paulo Research Foundation (FAPESP) for the doctor's scholarship granted and the financial support provided to develop this study (FAPESP Process 2009/14346-0). 